\title{
4. Precarious Resistance
}

The La Chapelle Protests, Paris, 2015-2016

"I made my way [to France] to have a better future, and now we are stuck here. We have rights, too! It is not much what we demand. We are grateful to those who show solidarity today. Today is the first day of hope since I arrived in France. Today at this demonstration, I feel human again."1

\begin{abstract}
In summer 2015, precarious migrants, mainly from the Horn of Africa and Asia, sought protection underneath an elevated metro line at La Chapelle, in the northeast of Paris. Dozens of tents, cardboard boxes and mattresses precariously accommodated several hundreds of protesters. From the moment the government intervened and broke up the makeshift camp, the situation, previously perceived as a humanitarian emergency, became increasingly contentious. This chapter scrutinizes the processes of political mobilization in the most disadvantageous contexts. It traces the visible and invisible acts of resistance by precarious migrants, incubated in autonomous spaces, such as makeshift camps and squats, where the interaction of migrants and supporters mobilized resources and temporarily created visible sites of contention.
\end{abstract}

Keywords: protest; asylum seekers; Paris; "bare life”; camps; squats

As an important transit hub for asylum seekers on their way to Great Britain, the French capital Paris used to be an important crossroads, where migrants seeking asylum rested for some days or weeks, but rarely settled for long. Most, eventually, headed further north toward Calais, trying to cross the English Channel, hidden in trucks or trains. Political mobilizations in support 
of and by asylum seekers, hence, primarily concentrated at the French border zones such as Calais and Nice. In many cases, migrants and their supporters mobilized in reaction to obstacles blocking the continuation of their journey, rather than demanding inclusion in France. In other words, most opted for "exit" instead of "voice."

The situation fundamentally changed in the context of the crisis of European migration politics in 2015, when precarious migrants, mainly from the Horn of Africa and Asia, arrived in the city. In the absence of governmental assistance, they sought protection underneath an elevated metro line at La Chapelle, in the northeast of Paris. Dozens of tents, cardboard boxes and mattresses precariously accommodated several hundreds, eventually. From the moment the government intervened and broke up the makeshift camp, the situation, previously perceived as a humanitarian emergency, became increasingly politicized. A series of protests unfolded with and around individuals in highly precarious situations: homeless in the streets, abandoned by the state and dependent on the support of civil society actors. Against this background, the chapter scrutinizes the processes of political mobilization in the most disadvantageous contexts. It traces the visible and invisible acts of resistance, incubated in autonomous spaces, such as makeshift camps and squats, ${ }^{2}$ where the interaction of precarious migrants and supporters mobilized resources and created visible sites of contention.

\section{Protest Emergence: Politicization of a Humanitarian Crisis}

From the second half of 2014 onward asylum seekers - mostly from Afghanistan, Iraq, Eritrea, and Sudan - started to gather underneath a metro bridge at La Chapelle station. In spring 2015 a makeshift camp had emerged, precariously accommodating more than a hundred individuals (Baumard 2015). Neighbors and humanitarian organizations jumped in to compensate for the vacuum left by an absent state and provided basic needs such as tents, mattresses, clothes and food (Interview P2, P10). As asylum seekers, many of those gathering under the metro bridge were formally entitled to public services by the French state. Yet, the situation unveiled a structural deficit. Considering itself mainly as a transit country for asylums seekers and deliberately intending

2 This book uses the term "squat" when the subversive appropriation of a building includes an element of providing shelter for precarious residents. If the purpose is mainly disruptive and protest oriented, it is referred to as an "occupation" (see Chapter 3 on the occupation of the Bourse du Travail). 
to avoid creating a "pull effect," France has been known for its chronically undersized system of asylum accommodation. A couple of numbers suffice to underline this fact: similar to other European capitals, the capital region of Île de France has for many years been a hotspot for arrivals and asylum applications. Nevertheless, in 2016, the entire region held a capacity of fewer than 9,00o places $^{3}$ for asylum seekers (Préfecture de Police Île de France 2016) for more than 18,000 asylum applications in 2015 alone (OFPRA 2016). Despite the structural causes of the makeshift migrant camps emerging in the French capital from summer 2014 onward, in the beginning, the situation was mainly perceived as a humanitarian emergency. Neighbors, shocked by these precarious existences at their doorsteps, organized the provision of basic needs and reached out to humanitarian professionals involved in care work.

The summer of 2015 initiated fundamental changes. With increasing arrivals of asylum seekers, the makeshift camp at La Chapelle grew further. Despite widespread support from the neighborhood with its dense associative networks, the conditions in the camp deteriorated - due to a lack of sanitary facilities and, more generally, overpopulation in an extremely limited space, squeezed in between two busy streets. After a months-long absence, and following increasing media coverage, public authorities intervened on 2 June 2015, with an evacuation of the makeshift camp (Sabot 2015), pointing at risks to public health and order (Préfecture de Police Île de France 2015). This first coordinated police intervention constituted a critical juncture, transforming a situation formerly perceived as a humanitarian emergency into a protest arena, in which a plethora of players interacted. ${ }^{4}$ During the dismantling of the camp, police forces blocked the area and transferred all migrants who were present at that moment with buses to temporary emergency shelters throughout the entire region of Île de France. Two humanitarian organizations involved in service provision for the government, France terre d'asile and Emmaüs Solidarité, co-coordinated the process. ${ }^{5}$ Over 300 migrants were relocated and the area was subsequently secured to avoid reinstallation. More than half of the

3 This number includes those in CADAs (reception centers for asylum seekers used for the entire asylum procedure) and emergency shelters, which provide only short-term housing. See also Chapter 2 for further details.

4 A more exhaustive descriptive account of the developments can be found in the section on Paris included in the booklet published by the research project Babels (Projet Babels 2017).

5 While a cleavage between "humanitarian" and "political" organizations was already latent in the migrant rights movement in France prior to the La Chapelle arena (Monforte 2014), the involvement in the evacuations by the state further (mutually) alienated those two organizations from the grassroots movement. 
evacuated persons were officially registered as asylum seekers in France and some had been already recognized as refugees under international law (Sabot 2015). Neighbors and activists who had been supporting the migrants during their precarious life in the camp observed the police intervention with suspicion, while some even tried to prevent the buses from departing (ATMF 2015; Sabot 2015). Particularly the strategy of dispersal applied by the public authorities without offering a sustainable solution for those in need of a roof spurred increasing resistance (Jaoul 2019).

Only a few hours after the buses had departed, precarious migrants started to gather again because they had missed the moment of transfer. On the evening of the first eviction, several dozen migrants and a handful of solidarity activists wandered around the eighteenth arrondissement of Paris, with mattresses and plastic bags containing their few belongings, in search of a place to spend the night. Food was collected through donations from various migrant-run restaurants and local grocery shops in the area (Interview $\mathrm{P}_{7}$ ). After two days, the group again counted around a hundred persons. Some had just arrived in Paris, others had returned to La Chapelle after a couple of days because their emergency accommodation had been only temporary or it was located remotely and cut them off from legal advice for their asylum procedure (Interviews $\mathrm{P}_{2}, \mathrm{P}_{9}, \mathrm{P}_{10}, \mathrm{P}_{20}$ ). For many of those providing support for the migrants in the camp for months, the intervention by the state had only aimed at hiding a structural shortage of asylum accommodation from the public eye (Sabot 2015; Jaoul 2019). Without a place to stay, migrants and a small group of supporters attempted to occupy the St. Bernard church, in an attempt to symbolically relate to the birth of the sans-papiers movement in the late 1990s. ${ }^{6}$

Nevertheless, the attempt was prevented by the police and the migrant group eventually settled down around the corner at Esplanade Pajol, until the police intervened again on 8 June 2015 (Jaoul 2019). This time, the state displayed its force and sent the riot police, the Compagnies républicaines de sécurité (CRS), to carry out the evacuation (Jaoul 2019; Interviews P2, P13). The use of force against peaceful asylum seekers fueled a deep indignation among neighbors and supporters. It contributed to the emergence of an increasingly politicized network, which perceived the precarious living conditions as a concrete failure of state response. In the aftermath of the police intervention at Esplanade Pajol, the collective La Chapelle en lutte ${ }^{7}$ was founded, involving a diverse mix of academics, radical left activists 
and newly politicized neighbors (Jaoul and Makaremi 2015; La Chapelle en lutte 2015). Members of the collective noted in an op-ed in the daily newspaper Le Monde:

The refugees [...] were arrested en masse: more than 40 have been transferred to an immigrant detention center. ${ }^{8}$ The eviction at Rue Pajol was of unprecedented violence, but the most shocking thing is that they have sent CRS units against around a hundred refugees in the streets, who are trying to survive, who need to understand where they are, what rights they have and how an asylum application works. (Jaoul and Makaremi 2015, author's translation)

With the collective La Chapelle en lutte, a heterogeneous and influential compound player emerged on the scene. In the following months, a cat-andmouse game unfolded between the police on the one side, and migrants and supporters on the other (Projet Babels 2017; Jaoul 2019). The events always followed the same sequence: a critical number of migrants gathered in the absence of alternative accommodation, sleeping at times on layers of cardboard on the asphalt, at times on mattresses, at times in camping tents provided by neighbors and supporters. As soon as a camp became large enough to attract (media) visibility and cause a disruption to the "order of things," government authorities, in cooperation with France terre d'asile (FTdA) and Emmaüs Solidarité, intervened to provide a temporary solution for the inhabitants of the camp by transferring them to emergency shelters. Many of these interventions - called "evacuations," "evictions" or "raids," depending on the political leaning - were conducted with a considerable amount of force by the police and a subsequent confiscation and destruction of its constituting infrastructure (Interviews $\left.\mathrm{P}_{2}, \mathrm{P}_{7}, \mathrm{P} 10\right) .{ }^{9}$ These contentious interactions with the state incubated the contention further, which rapidly expanded and also attracted experienced antiracist activists and leftist party representatives who had been largely absent as long as the situation was perceived as a humanitarian emergency.

Precarious migrants, supporters and public authorities subsequently held diametrically opposed interests concerning the emergence of the camps: the city of Paris and the police fundamentally resisted the establishment of makeshift camps as they opened up a visible protest arena in the public space, which raised the question of governmental nonresponse. Thus, in

8 Literally "centre de retention administrative."

9 See also Jaoul (2019). 
order to discourage their perpetuation, the municipal authorities refused to provide sanitary facilities or other basic infrastructure, such as mattresses, blankets, and the like. For precarious migrants, in turn, the grouping in camps constituted a strategy of protection and survival but increasingly also a strategy to pressure the government to take action.

The individual stories and backgrounds of the migrants living in the camps were highly diverse. Yet, many had spent long and tiresome periods of (trans)migration: some through the Balkan corridor, some through Libya and Italy before arriving in Paris. Among them a Sudanese student of business administration, who had in the context of the so-called Arab Spring organized protests against the former dictator of Sudan, Omar al-Bashir. Terrified by the repression in Sudan, he escaped to Libya, and finally made his way to Greece via the Balkan route. Arriving in Calais, he paid $€ 1,000$ to be smuggled across the English Channel in a truck, as he expected to find better chances of social inclusion in the United Kingdom, given his fluency in English. However, he was detected and prevented from crossing. With all his money gone, he was stranded in the makeshift "jungle" of Calais, where he fell sick and came to require medical assistance. In summer 2015, he returned to the French capital and ended up living in the streets. He concluded his story by saying: "France was not my destination, but it became my destiny" (field notes, 21 June 2016). Another example is a young man from Darfur, who crossed the Mediterranean in an overcrowded rubber dinghy. When he arrived in Italy, he encountered an overburdened reception system and the Italian authorities gave him money to continue traveling north. At the border between Italy and France, in Ventimiglia, he got stuck for weeks as he was repeatedly detected and sent back during his attempts to cross the border. Eventually, he reached Nice and moved on to Paris. Directly after he arrived in the French capital, he ended up in one of the makeshift camps (field notes, 19 June 2017). There were also many Eritreans escaping the indeterminate military service in the country and many young Afghans, ${ }^{10}$ who had escaped organized crime, "mafias" as they called it, and the Taliban militias (field notes, 8 June 2017).

As diverse the individual stories prior to their arrival in Europe were, they became much more alike from the moment of arrival in Paris. Most were stranded in the northeast of the city, for various reasons. Firstly, with the two railway stations (Gare de l'Est and Gare du Nord), the northeast of Paris is the main "gateway to Paris" (Interview P11) and an exit point for

10 On the context of violence in Afghanistan, see Chapter 6 on protests in Berlin against deportations of refugees to Afghanistan. 
those heading north toward Calais. Secondly, the main access point to the asylum system in Paris is located in this part of the city. In France, asylum seekers were until 2015 required to go to a so-called Plateforme d'accueil des demandeurs d'asile (PADA), ${ }^{11}$ run by the nongovernmental organization FTdA, in order to make an appointment with the prefect's office where their asylum claims are officially processed. The PADA of Paris is located within walking distance of the two railway stations. Thirdly, the neighborhood has become well-known for having a large number of civil society organizations as well as exhibiting solidarity with refugees by providing for their basic needs. The names of the La Chapelle, Stalingrad, and Jaurès metro stations, hence, soon circulated within migrant communities. From spring 2015 onward, many asylum seekers waited several weeks to be registered in the PADA and sometimes several months for an appointment at the prefect's office. Others had already filed their asylum claim but were not provided with accommodation, given the structural shortage outlined above. Some were even recognized as refugees but were not able to find housing, given the lack of language competence and limited revenues.

\section{Makeshift Camps as Spaces of Survival and Precarious Resistance}

In the absence of shelters provided by the state, migrants organized protection and survival in groups. Many gathered - often clustering along nationality and language - in the few public spaces providing minimal protection from both sun and rain, predominantly bridges, tunnels, and parks. With very scarce financial means, lack of information, and minimal French linguistic skills, the daily life for those (several thousand) living in the streets turned out to be extremely burdensome. "After I came back from Calais, I was tired of the long journey. I decided to stay. And I ended up in the streets. You have nothing more to lose. You have lost everything. You lose your basic human dignity" (Interview P20). Many had to rely completely on charity soup kitchens or the goodwill of French citizens. The hardship and frustration of living in extremely precarious circumstances is mirrored in countless testimonies:

I took the train toward the country I'd dreamed of visiting ever since my childhood. But in reality it was a real shock to find myself utterly dispossessed in the rain, cold and hungry in the heart of the so-called 
"city of lights." I'm sick and my health is not compatible with the suffering and the misery of the street camps. (Merhaba 2016b)

For thousands of asylum seekers from spring 2015 onward, basic survival and shelter became the main priorities. Reduced to being "human as such," these individuals found themselves in a condition of "bare life" (Agamben 1998), stripped off or without access to rights, and in a state of exception, in which violence was rarely sanctioned. ${ }^{12}$ The camps became a dehumanizing marker and sites of despair. Despite these dire conditions, the majority remained quiet, instead of protesting against their blatant exclusion and precariousness. They were trapped in a paradox. "[The life in the streets] means a lot of stress, but you do not have a choice. People say: stay calm, there are many like you in France. Keep quiet, eventually it will work out, be patient" (Interview $\mathrm{P}_{2} 6$ ).

On the one hand, many felt outraged by the nonresponse of the state (Interviews $\mathrm{P}_{7}, \mathrm{P}_{10}$ ). Yet, on the other hand, they were well aware of the ultimate dependence on the state to obtain shelter, assistance and ideally a regularized status. This legal and moral reliance is intrinsic in the system of international protection:

I have been a refugee two times in my life. Asylum seekers are in a fragile situation; often it is your very skin that is in danger. [...] You are not a political subject; you are a political object. I was active before I came here, and then here, there was this sense of not wanting to give a bad impression. This sense of: "I demanded protection from this state and I have to respect the state." That is why there need to be extremely severe circumstances for a claims-making movement to come into being. (Interview P18)

The combination of "bare life" and the ultimate dependency on the state made the makeshift camps precarious spaces of survival. In the absence of established migrant networks from the countries of origin, including Somalia, Sudan, Eritrea, and Afghanistan, migrants were de facto entirely dependent on the care work of neighbors and humanitarian professionals. Humanitarianism, in turn, clearly has contradictory effects on agency, as it both alleviates suffering and risks reproducing patterns of dependency, subordination, passivity, and apathy (Ticktin 2011; Fassin 2012).

Yet, as the trajectory of protests at La Chapelle documents, the makeshift camps gradually became more than spaces of survival. They transformed into 
protest arenas, in which visibility could be generated and scarce resources mobilized. On the evening of the second large evacuation at Esplanade Pajol, the local community garden, Bois Dormoy, in the same neighborhood opened its door to the migrants from the camp who had neither been evacuated, nor been taken to a deportation facility (Derveaux 2015). Even though the association in charge of the garden underlined that they could only host the migrants for a couple of days, the space provided temporary protection from the constant policing of the previous days (Interview $\mathrm{P}_{7}$ ). In this moment of recovery, the garden served as a space of encounter and politicization for migrants and supporters. First general assemblies were held in which the different communities of migrants expressed their demands (Jaoul 2019; Interviews $\mathrm{P}_{2}, \mathrm{P}_{7}$ ). The violent police intervention had also expanded the set of supporting actors. Besides neighbors and those few activists who had accompanied the migrants since the first governmental intervention, political activists and politicians from left and radical left parties entered the protest arena as additional players (Mouillard and Durupt 2015; Derveaux 2015). In their op-ed in Le Monde, two supporters underlined the empowering and incubating effect of these early experiences in autonomous spaces:

These fights have shown the necessity of spaces, where migrants have access to associations and to the solidarity of the neighbors. [...] It is paramount to get out of the miserable situation in the streets [...] and the cold of administrative governance, which often categorizes arbitrarily and bans migrants from our streets, from our cities, from our lives. (Jaoul and Makaremi 2015)

After leaving the premises of the garden the diverse group occupied the abandoned firefighters' barracks at Château-Landon (Le Monde Online 2015), in close proximity to the previous sites of contention. During this action, profound conflicts emerged among the supporting factions, particularly between those with an autonomous tradition and those affiliated with parties (Interview $\mathrm{P}_{7}$; Jaoul 2019; Lamothe and Fischer 2015). While some of the supporters were the first line in the occupation, others attempted to discourage migrants from participating in order not to take risks. This in turn, spurred fierce resistance by other fractions, who qualified such interventions as paternalistic and against the deliberate decisions taken by the migrants themselves (Interview $\mathrm{P}_{7}$ ). The growing heterogeneity of the supporting players incubated the protest, yet, soon also resulted in conflicts on strategy, forms of action, and the role of migrants in collective decision making (Interviews $\mathrm{P}_{7}, \mathrm{P}_{2} 8$ ). Shortly after entering the barracks, 
riot police blocked the building. Subsequently, in negotiations between the occupants and the town hall of Paris, an agreement was made. This resulted in the transfer of over a hundred migrants to emergency shelters (Le Figaro Online 2015a), where they were allowed to stay for a maximum of one week. The issue became further politicized thereafter, attracting the attention of high-ranking politicians. In a joint press release, Minister of the Interior Bernard Cazeneuve and Mayor of Paris Anne Hidalgo (both of the Socialist Party), accused supporters of "cynically exploiting for purely political reasons the dramatic situation of migrants" (Le Figaro Online 2015a, author's translation).

Within a very short period of time, the camps and the presence of migrants had been transformed from a humanitarian emergency into a visible rupture of the political life in Paris. In this protest arena, a multitude of individual and compound actors with distinct, often opposing, interests and stakes interacted. Accordingly, after the occupation of the firefighters' barracks at Château-Landon: "There was a lot of pressure on the camps. They lasted two, three weeks and then there was an evacuation. Then the conflicts in the solidarity movement started. I tell you this, because such moments mean something. ${ }^{13}$ After that, it is very difficult [for participants] to work together again" (Interview $\mathrm{P}_{7}$ ).

Through these contentious interactions involving migrants, supporters, and government authorities, the camps were transformed from spaces of mere survival to sites in which precarious resistance sparked. Immediately following the occupation, migrants started gathering again in the neighborhood: individuals who had just arrived in the capital, those who had not been included in the agreement with the city hall and, after a week, some of those who had to leave the temporary shelter as well. Due to the increased media coverage and social media channels recently established to coordinate the scattered migrant support groups, the subsequent camps attracted a wide range of individuals and associations offering all kinds of services from food and tents, to language courses, legal assistance, and spaces for political exchange (Interviews $\mathrm{P} 2$, P1o). The initial self-help arrangements of makeshift camps, hence, started to become also spaces of precarious protection, pools for resources and sites of recognition. The involvement of a wide range of actors criticizing the governmental nonresponse and providing resources altered the options for those precarious migrants, who were pushed toward a burdensome life in the streets. While interacting with all actors involved in the arena, the inhabitants of the camps were 
never purely objects of care, political exploitation or governmental administration, as they were often presented. The makeshift camps constituted ambivalent spaces in this regard. On the one hand, the conditions in the makeshift camps served as important stigmatizing markers and reproduced marginalization. On the other hand, the camps opened niches for agency, through their protective, relational, and disruptive qualities. For most, the initial rationale for gathering in makeshift camps was a temporary means for basic protection, to stay in groups and to share scarce resources. Indeed, the individuals had all kinds of reasons for joining a makeshift camp, and even to avoid evacuation. Some saw it as a place for temporary recovery before moving on. Others expected better chances to access legal advice in central Paris compared to the remote emergency shelters (Baumard 2016c).

Nevertheless, the increasing politicization and the visibility of the camps gradually added a strategic element. Publicly displaying a social problem, the camps transformed protest arenas with a large audience, which became bothersome for the authorities and forced them to concede places in emergency shelters. Hence, the gathering of migrants, the presence of migrant bodies in the streets, attracted attention to the issue itself. It was in line with Butler's ideas on the performativity of assemblies (2015) being fundamentally political. In this vein, a migrant "who will not play his assigned role, who no longer stays in his place, who does not keep silent" (Agier 2010: 42) creates a rupture in the established order, and performs a "right to have rights." Indeed, many inhabitants of the camps certainly were not interested in the symbolic dimension of their disrupting effect. However, they were aware and willing to exploit it instrumentally: "The priority was to get a roof, so when the camp helps to achieve this, great - we do it!" (Interview P24). ${ }^{14}$ Indeed, in quantitative terms, the strategy to obtain shelter through camps and evacuations was highly successful: between June 2015 and November 2016, the north of Paris witnessed the emergence of dozens of makeshift camps, accommodating between a hundred to at times several thousands of persons. According to official sources, 21,728 (often temporary) places in emergency shelters were offered, following more than 30 evacuations of makeshift camps (Préfecture de Police Île de France 2016).

In addition to providing protection and exerting pressure on the government, the camps at times unfolded relational effects, generating trust among the diverse migrant communities, and mobilizing resources through social ties with individual supporters and associations (Jaoul 2015b, 2019). At many makeshift camps, language courses and legal advice were organized on the 
spot, in this regard, providing more advantageous conditions than in most of the isolated emergency shelters offered by the state with usually poor access to services (Interview $\mathrm{P}_{30}$ ). Many returned regularly from remote shelters to the camps to access these crucial resources or eventually opted to move back for good (field notes, 19 June 2017; Interviews P26, P30).

As combinations of everyday survival and spaces of encounter the camps were sites in which public articulation of dissent by disenfranchised migrants sparked. In most camps, assemblies were held, often with translations into multiple languages (Interviews $\mathrm{P}_{7}, \mathrm{P}_{10}, \mathrm{P}_{30}$ ). Depending on the respective camps and their inhabitants, it was decided whether "silence" or "voice" was the preferred strategy to obtain accommodation and access to rights more broadly. The camps became arenas of internal debate and strategizing themselves: "Of course every camp was different, as heterogeneous as the migrant population. In some camps, the migrants wanted to do something politically. They are there and wait, and some want to use this time to do something. This offers a moment to discuss and organize" (Interview P10).

In the context of heavy policing, others considered public articulation of dissent as an additional risk in an ongoing or upcoming asylum procedure, or for the "Dublin cases," increasing the danger of imminent deportation to another EU country (Interviews $\mathrm{P}_{10}, \mathrm{P}_{13}, \mathrm{P}_{23}$ ). In some camps, instead, the inhabitants chose to make their voices heard, organizing rallies and sit-ins, drafting flyers, or putting up banners with claims around the camps (Jaoul 2019). During these traditional protest events, both general dissent and specific demands were articulated (Jaoul 2019): signs showed slogans such as "we want human rights," "there are no human rights in France," "humans, not beast," "stop Dublin," "we demand asylum," "we want dignity" (NPA 2015; Degeorges 2016; ATMF 2015; La Chapelle en lutte 2015). While the decision to act and the specific claims were developed by the inhabitants of the camps, the infrastructure, such as material for banners and megaphones, were provided by supporting individuals and groups. Public demands were not only articulated during demonstrations but also in print and online publications emanating from the camps. One of these communiqués read: "We are a group of migrants and refugees. We demand our rights as they are provided by the law. We camp in a square, at the moment, we are on a sidewalk. [...] We demand an acceleration and facilitation of the asylum process. That a sustainable and decent accommodation is found for refugees. We stay here until a solution is found." ${ }^{\prime 5}$ Testimonies and demands of this kind were either published on social media, the alternative media platform 
Mediapart, or printed in the five issues of the grassroots magazine Merhaba, which had been created by migrants and supporters in the camps.

The temporary shift from silence to voice resulted from the interactions among a heterogeneous set of migrants as well as migrants and supporters in the makeshift camps. Over time basic trust, empowering emotions (of indignation rather than fear) and access to minimal resources could be achieved. Yet, these interaction involving highly diverse actors did not always unfold empowering effects. Not least due to the precarious living conditions, and a consequential instrumental reasoning. Accordingly, those inhabiting the camps did by no means always welcome the diverse mix of supporters with open arms, suspicious by the countless negative experience made.

[T] hey asked "but why do you come here, if you cannot do anything for me?" [...] [The migrants] see so many people, the police, the OFII, ${ }^{16} \mathrm{FTdA}$, they do not know anymore, who is who, who does what. Some associations help us, others put us on a bus and take us to the middle of nowhere. Trust is difficult. In fact, it is only with a regular presence on the ground that you gain the trust of the people. [...] It helped us also that we have a lot of migrants in our group, who have been living in the camps, who work with us now. This facilitates trust building. (Interview P10)

While in some camps, the inhabitants opted for overt protest, in others, they explicitly asked supporters to remain patient and quiet. Often it depended on the subjective assessment of the advantages and risks of the respective strategy (Interviews P10, P24). Both remaining silent and expressing voice had become strategies, upon which migrants had a novel degree of choice. A young woman who lived in various camps and decided to join protest activities reflected:

[P]eople [referring to fellow migrants] attacked me a lot, saying, "Stop it, you will not get your case approved - they never give you papers if you are in an association or active, because in Europe they want people quiet. And if they meet me now, they say, "Still no answer from OFPRA? We told you, it is because you are involved." (Interview P24)

The makeshift camps, hence, remained ambivalent spaces of both survival and precarious resistance. Due to their function as a space for civil society

16 Office français de l'immigration et l'intégration (French Office for Immigration and Integration). 
engagement, migrant agency and governmental critique, the camps encountered increased policing to prevent their emergence or were rapidly dismantled (Jaoul 2019). As protest arenas in public, space, the state attempted to impose its rules to break up contention.

\section{A Migrant Squat as a Space of Incubation and Alienation}

Despite its strategic value, the cycle of makeshift camps and evacuations reached a deadlock. Only when larger camps emerged and attracted visibility, did the administration react with the provision of (often temporary) accommodation. Due to the continuing arrival of more migrants in the city and the return of those who had only obtained temporary shelter, no sustainable solution appeared in sight (Interview P23). To increase the pressure, by the end of July 2015, activists from the collective La Chapelle en lutte, who had already advocated for squatting in the firefighters' barracks at Château-Landon, together with several dozen asylum seekers, mostly from Afghanistan and Sudan, decided to squat in an abandoned school building (the Lycée Jean Quarré) in the nineteenth arrondissement (Interviews P23, $\mathrm{P}_{27}, \mathrm{P}_{2} 8, \mathrm{P}_{30}$ ). Besides providing shelter for migrants living in the streets, the squat was explicitly understood as a prefiguration of alternative migrant accommodation schemes - self-organized and centrally located (Coutant 2017). ${ }^{17}$ Immediately after squatting in the Lycée Jean Quarré building, it was rebaptized as "La Maison des Réfugiés” (The House of Refugees). Accommodating around 150 migrants at the outset, the squat initially received overall supportive media coverage (Lamothe and Le Gohébel 2015; Lamothe 2015; Le Figaro Online 2015b). The city of Paris also declared it would temporarily allow the squat.

Due to its visibility, the squatted building initially had an incubating effect. Given the lack of alternative housing options for precarious migrants, the squat grew rapidly in size. In addition, the inflow of donations was immense at first. This was also due to the simultaneous diffusion of images of a deceased Syrian boy, Aylan Kurdi, which fueled widespread solidarity with migrants in Paris. For a moment, the squatted school absorbed this indignation and support by parts of French society. Usually, a simple post in social media channels or an information board displayed at the entrance sufficed to attract the material resources needed to sustain the place. The

17 The squat as a form of action to politicize (migrant) marginalization has a long tradition in France (Péchu 1999; Aguilera 2013; Bouillon 2017). 
accumulation of resources, ranging from clothes to language courses, medical support and legal advice in addition to a solid roof further increased the squat's appeal for those migrants still living in the streets of Paris. Assembling a diverse mix of actors, similarly to the makeshift camps, but initially with more advantageous spatial characteristics (large building, a courtyard), the squat turned into a vibrant hub of social encounters and precarious resistance (Interviews $\mathrm{P}_{2} 8, \mathrm{P}_{30}$ ).

On the other hand, after a while, the building was bursting at the seams. Both overpopulation and a lack of internal organization of the temporary gathering of more than a thousand migrants increasingly spurred conflicts over sanitary facilities or the use of communal spaces (Interviews $\mathrm{P}_{23}, \mathrm{P}_{30}$; Coutant 2018). The building became a protest arena on its own, in which players tried to pursue their individual and group interest observed by an increasingly critical audience. Both media reports and the public authorities at the local and regional level subsequently shifted and predominantly pointed to the degradation of the place and suspected its exploitation by the radical left. Its inhabitants, more than a thousand migrants, were mainly portrayed as either victims of leftist activism or as a troubling mass. Yet, for those inhabiting the squat, the situation was highly ambivalent. Indeed, the squat unfolded highly contradictory relational and spatial qualities for the emergence and incubation of migratory dissent.

The very fact that the number of inhabitants in the squat steadily grew from the point of its establishment to the time they were evicted, illustrated - despite the dominant negative media coverage - that many migrants still considered it as the best among very poor alternatives. Many asylum seekers who had been assigned accommodation in emergency shelters spent the day in the squat anyway, often because that was where they could access resources they could not find elsewhere - including French classes, primary medical care, legal support and others' company. Such benefits were often hard to find in the remotely located provisional accommodation facilities offered by the state (Interview $\mathrm{P}_{30}$ ). Many migrants found space to develop a collective identity and engage in political organizing. Supporters, in turn, even those with a primarily humanitarian impetus, were confronted with the tremendous hardship of exile, disenfranchisement and poverty, experiences which they were unlikely to have experienced themselves. Accordingly, the space of the squat allowed for an intensified organizing compared to the makeshift camps in the streets. General assemblies were held with delegates from various migrant communities. Two large demonstrations were organized in the squat. Inhabitants worked on Merhaba, a movement 
journal published in French, English, Arabic, and Dari in five issues in 2015 and 2016 to share testimonies, experiences, and demands (Interview P1o). One of the young Sudanese who became increasingly engaged politically in the squat noted: "The people [...] were really enthusiastic to buy banners or write slogans. They were very responsive to the idea. They were eventually aware of their rights and wanted to take collective action to let people know that their rights were being abused" (Interview $\mathrm{P}_{30}$ ).

For those who wanted to express "voice" publicly, the interactions unfolding in the squat were initially beneficial. Given the heterogeneity of the squat, by far not all inhabitants were interested in any kind of visible protest activities. Similar to the makeshift camps, many regarded the precarious squat as a pragmatic solution for very concrete problems: access to shelter, to the asylum system and legal and social support. Indeed, many inhabitants of the squat maintained a profoundly skeptical attitude toward the politicized activists of the La Chapelle en lutte group (Coutant 2018; Lamothe and Fischer 2015). Some Afghans, for instance, thought that it was not in their interest to enter into confrontation with the state, as their chances of being granted asylum appeared at that time reasonably high. Once more, the delicate position of simultaneously challenging and claiming the right to asylum from the state became evident and led to conflicts over the confrontational agenda of parts of the supporters (Coutant 2018).

Whereas the first phase of the squat was predominantly characterized by an incubating dynamic, over time mutual alienation and exhaustion due to the precarious conditions prevailed. With a growing number of inhabitants, degradation and conflicts multiplied, which, in turn, accentuated divisions among the different factions of supporters, among the migrant communities and between public authorities and supporters. When the donations for the squat ebbed due to increasingly critical media coverage (France Info 2015; Simon 2015), the competition for scarce resources ever more frequently escalated to physical conflicts:

People were grouped according to nationalities. Rooms were divided and some did not let others enter. There was the Afghani room, the Eritrean room, the Syrian room, the Sudanese room, the Iraqi room - they were afraid of each other. It is true that there was no trust. [...] The situation there was also very stressful. People started to feel exhausted and they could not take it anymore. [...] They fought with each other because there was not enough space to sleep. People started taking the belongings of others. (Interview $\mathrm{P}_{30}$ ) 
Furthermore, the relations with the neighborhood of the squat increasingly deteriorated over time. As Isabelle Coutant pointed out in her detailed analysis of the squat and its resonance in the neighborhood, the arrival of a large number of migrants added to the already existing challenges in one of the most underprivileged areas of the French capital (Coutant 2018). Indeed, the transformation of the abandoned school into a self-organized migrant shelter collided with plans to open a media lab for the local population in the facilities. Many neighbors considered it unfair that their area of the city was unwillingly dragged into bearing additional burdens. The visible overpopulation and degradation of the place fueled the opposition in the neighborhood but also among the local administration and the city of Paris.

Less than a month after its establishment, the squat had become predominantly portrayed as the emblematic result of ill-guided migrant support activism. Including the traditionally left-leaning newspaper Libération, which published a highly critical article on the squat, mainly criticizing the group La Chapelle en lutte for its dominant role and its "self-isolation" from both public authorities and the professional humanitarian organizations (Lamothe and Fischer 2015). Not least due to their exposure to the horrendous deprivation of many individuals inhabiting the place, the supporters in the squat had become increasingly critical toward the "placebo" response of the government and their role in creating the situation in the first place. In their view, media reports exclusively highlighting the existing and yet problematic conditions in the squat were merely reproducing governmental discourses aiming at discrediting migrant solidarity and hiding the underlying systematic failure of the government response (Jaoul 2015a). Indeed, the absence of shelters had pushed more and more migrants into the squat, which contributed to its accelerated degeneration. The spatial qualities and rules of the protest arena at the Lycée Jean Quarré differed from the makeshift camps in important ways: while the camps exposed a social problem and the failure of the state to a broader public, the spatiality of the precarious squat sealed in the problems and allowed the shifting of the responsibility to the migrant support groups.

Soon, the situation reached a stalemate. Relationships between La Chapelle en lutte and the state were cut. Notwithstanding, given the proliferation of problems in the squatted building, the migrant inhabitants increasingly demanded a sustainable solution. In reaction to the deadlock in negotiating a way out of the impasse, neighbors formed a new group, taking neither the side of the public authorities nor that of La Chapelle en lutte. The emerging new actor, Solidarité migrants place des Fêtes, was 
mainly preoccupied with the social cohesion in the neighborhood, but also expressed its solidarity with the migrants living in the squat (Coutant 2018). Various attempts at mediation, involving representatives of the largest migrant communities in the squat and the local administration, failed. Eventually, the city of Paris issued an evacuation warrant. Almost three months after its establishment, on 23 October, the police evacuated the building, transferring more than 1,300 inhabitants to emergency shelters (Le Monde Online 2015). For many migrants living in the squat, but also for most of the supporters, the evacuation was a relief. The conditions in the squat had become untenable, external support had eroded and the external pressure on the squat had led to an internal fragmentation of the heterogeneous group La Chapelle en lutte (Interviews $\mathrm{P}_{23}, \mathrm{P}_{3}$ ). One of the squatting migrants summarized the dynamic as follows: "It was great that we occupied this place. We did not have an alternative. And we organized many things there. [...] But I was really happy when it was evacuated because it had become unbearable" (Interview $\mathrm{P}_{30}$ ).

On the one hand, the absence of the culminating place underlined its importance in hindsight. During the squat, the idea was born to create a self-organized migrant association, to ensure sustainability and selfrepresentation (Interviews $\mathrm{P}_{20}, \mathrm{P}_{23}$ ). While the accentuating conflicts and everyday challenges in the overpopulated squat in the end absorbed everyone's energy, the period after the evacuation proved to be even more challenging: "Afterward it was difficult because only 10 percent were in Paris and the rest was sent out of Paris. [...] When they moved to the emergency shelters and they were separated, a lot of this spirit was gone. [...] In the squat it was easier because everyone was in the same place" (Interviews $\left.\mathrm{P}_{23}\right)^{18}$

On the other hand, the profound dynamics of alienation resulting from the contentious interactions in the squat left lasting ruptures. In the aftermath of the evacuation, La Chapelle en lutte fell apart, fragmenting into various groups and associations. Among them were the United Migrants, focusing on the asylum seeker self-organization La Chapelle debout, ${ }^{19}$ which advocated a confrontational approach, and BAAM (Bureau d'accueil et d'accompagnement des migrants), which set up a political, yet pragmatic support association (Interviews $\mathrm{P}_{2}, \mathrm{P}_{23}, \mathrm{P}_{27}, \mathrm{P}_{2} 8$ ).

18 A similar point was made in Interview $\mathrm{P}_{3}$.

19 The Paris chapter of the nationwide Nuit debout movement unfolding in France in spring 2016 drew heavily from the resources and links established during the mobilizations around migration. Many members of the La Chapelle debout collective previously involved in the camps and the squat document this personal continuity (Interviews $\mathrm{P}_{23}, \mathrm{P}_{2} 8$ ). 


\section{Fading Contention: Internal Division and the Humanitarian Governance}

The end of the squat meant by no means the end of the protests. As in previous evacuations, some inhabitants had missed the moment and were not allocated a place in emergency accommodation. Others came back to Paris after a few days. Consequently, the cat-and-mouse game of street camps picked up steam again, involving both former inhabitants of the squat and parts of the supporters. Not least due to the experience in the politicized squat, the subsequent makeshift camps were explicitly understood as sites of contention (Degeorges 2016; Merhaba 2015c, 2016a, 2016b):

The mayor's office said it would accommodate us but it was a lie; some were taken but other refugees were left in the street. We need housing and documents. We're here [in front of the city hall] to find a solution to our situation today. Our priority is to have a roof above our heads. [...] They evacuated the others from the high school but we're still outside. The mayor's office lied to us. They broke their promise. (Merhaba 2015c)

Following yet another series of makeshift camps, La Chapelle debout together, with over 300 migrants, occupied another abandoned school building: the Lycée Jean Jaurès (Pouliquen 2016). Drawing from the lessons learned during the squatting in the Lycée Jean Quarré and its undoubted mistakes (Interviews $\mathrm{P}_{23}, \mathrm{P}_{27}$ ), the rules in the Lycée Jean Jaurès were much stricter and more self-organized involvement by the inhabitants was demanded. Moreover, La Chapelle debout intended to bridge the neat division between "refugees" and "sans-papiers" that had characterized the mobilizations at La Chapelle. Indeed, the well-organized sans-papiers collectives had, so far, kept their distance from the unfolding protests. One of the protagonists of the Bourse de Travail protests ${ }^{20}$ noted:

We were there at the beginning, but the supporters did not want us there. They said: "This is not your struggle. These are asylum seekers and you are sans-papiers. This is something different." I said: "But half of them will be rejected and they will become sans-papiers." [...] [And] they said to the people there [precarious migrants at La Chapelle]: "Your situation is different; you have much better chances to get a residence permit!" [...] Anyhow. The thing is, we do not forget. (Interview P14) 
The distinction in asylum seekers and undocumented migrants was not only made by some of the supporters, but also by many migrants in the camps themselves. For those who aimed at refugee protection, mingling with the sans-papiers meant mingling with those who "failed" (Interviews $\mathrm{P}_{27}$, P29). While some of the precarious migrants intended to get into the asylum system as asylum seekers, the sans-papiers never had a chance or were expelled from this very system. In the light of their precarious living conditions and scarce resources, the established sans-papiers collectives observed with suspicion a concentration of resources around the "refugees" at La Chapelle at the expense of a visibility and support for "their" struggles (Interviews $\mathrm{P}_{14}, \mathrm{P}_{22}$ ).

Aware of these divisions, the La Chapelle debout group, whose members shared the criticism of categorizing precarious migrants, proactively invited the experienced collectives of undocumented migrants (including the $\mathrm{CSP}_{75}$ ) to join the squat (Interviews $\mathrm{P}_{28} 8 \mathrm{P}_{27}$ ). This time, the squat was not evacuated, but evicted by the police two weeks after (Baumard 2016b). In contrast to previous experiences during the series of protests, none of the inhabitants were transferred to emergency shelters, and instead many were directly taken to deportation facilities. The state showed its muscle, presumably because the squat risked becoming a site of even greater contention, given its attempt to bridge two networks of activists that were, so far, largely disconnected. Disillusioned by the heavy repression, the activists refrained from squatting afterward and the Lycée Jean Jaurès remained the last squat of the series of protests.

In order to prevent new camps, the government intensified the policing of emerging agglomerations of migrants in the streets, confiscating tents, mattresses and cardboard boxes but also setting up material obstacles. Open public spaces underneath metro lines, and various parks got fenced (Jaoul 2019). One of the migrants living in one of the camps observed: "They are about to set up barriers everywhere in the neighborhood. [...] Afraid of camps being set up again, they have closed the space under the elevated metro line at Stalingrad and they have fenced the Jardins d'Eole [metro stop]. They built a landscape of walls, like at the borders" (Baumard 2016a, author's translation).

In the absence of alternatives, migrants continued to gather and they slept scattered on the walkways and parks with even less protection against heat, rain and cold (Interviews $\mathrm{P}_{2}, \mathrm{P}_{5}, \mathrm{P} 8, \mathrm{P} 10$ ). Including the established Médecins sans frontières (MSF), humanitarian organizations publicly denounced the "systematic police violence targeted against migrants wandering through the city" (MSF 2016). Given the tightened policing, migrants and the exhausted 
and fragmented supporters encountered increasing difficulties to establish and maintain the street camps:

We are migrants. We are homeless. We are in the Place de la République. We cannot sleep. It's raining. Every time we put up tents [...] the police push us and take the tents by force. So we are staying in the rain and in the cold without cover all night. [...] We are not criminals. We want respect. We want rights. We want humanity. We want accommodation today. We will never give up until you accept our requests. We call on the people to help the refugees. ${ }^{21}$

In November 2016, the cycle of makeshift camps stopped abruptly. The city of Paris had adopted a new strategy in addition to policing to address the issue of both accommodation and contention. A large center of first reception for asylum seekers at Porte de la Chapelle was opened (Couvelaire 2016). From this moment onward, the center became the bottleneck into public services. Most migrants started settling around the center, hoping to get one of the 400 places. At the same time, the police controlled the outskirts of Paris even more fiercely, confiscating tents and putting massive boulders on the sides of the road where camps could be erected. Combining humanitarian governance and policing the state had taken over. Frustrated and exhausted, many supporters left the terrain, and the protests cooled off in the winter of 2016, even though hundreds of precarious migrants still remained without shelter and access to rights in the streets of Paris.

\section{Conclusion}

The La Chapelle protests unveil dynamics of migratory dissent in most disadvantageous contexts. Reduced to a condition of "bare life," precarious migrants got stranded in the streets of Paris, destitute and dependent on governmental and civil society assistance. Due to the precarious lives and dependence on the state, the forms of resistance that unfolded differ from other protests portrayed in this book. These precarious acts of resistance were rather instrumental, aiming at solving immediate individual problems such as access to accommodation and legal advice during the asylum procedure. Notwithstanding, in the contradictory spatialities of makeshift camps and squats, the contentious interactions with the police 
as well as a heterogeneous set of supporters allowed transforming feelings of indignation and dehumanization to be temporarily transformed into political mobilization. Despite the relational and disruptive qualities these precarious autonomous spaces unfolded, social ties with pro-beneficiaries and within diverse migrant communities were also highly fragile and prone to fragmentation in a context in which resistance is a mode of survival that necessarily prioritizes basic needs over long-term mobilization.

\section{References}

Agamben, Giorgio. 1998. Homo Sacer: Sovereign Power and Bare Life. Stanford: Stanford University Press.

Agier, Michel. 2010. "Humanity as an Identity and Its Political Effects (A Note on Camps and Humanitarian Government)." Humanity: An International Journal of Human Rights, Humanitarianism, and Development 1 (1): 29-45.

Aguilera, Thomas. 2013. "Configurations of Squats in Paris and the Île-de-France Region: Diversity of Goals and Resources." In Squatting in Europe: Radical Spaces, Urban Struggles, edited by Squatting Europe Kollective, 209-23o. Brooklyn: Autonomedia.

ATMF. 2015. "Migrants de La Chapelle." http://www.atmf.org/?p=3978.

Baumard, Maryline. 2015. "La 'jungle' de La Chapelle bientôt évacuée." Le Monde

Online, 29 May. http://www.lemonde.fr/societe/article/2015/05/29/commentsortir-de-la-jungle-parisienne_4643064_3224.html.

— . 2016a. "Demandes d'asile: les modestes records de la France." Le Monde Online, 7 June. https://www.lemonde.fr/immigration-et-diversite/article/2016/o6/o8/ asile-les-modestes-records-de-la-france_4942871_165420o.html.

—. 2016b. "Expulsion manu militari des migrants du lycée Jean-Jaurès." Le Monde Online, 4 May. http://www.lemonde.fr/immigration-et-diversite/article/2016/05/04/ expulsion-manu-militari-des-migrants-du-lycee-jean-jaures_4913756_1654200. html.

—. 2016c. "Migrants: à la Halle Pajol à Paris, l'éternel recommencement." Le Monde Online, 24 June. http://www.lemonde.fr/immigration-et-diversite/ article/2016/o6/24/migrants-a-la-halle-pajol-a-paris-l-eternel-recommencement_4957591_165420o.html\#uIoSgDIGAsevplot.99.

Bouillon, Florence. 2017. "Why Migrants' Squats Are a Political Issue: A Few Thoughts about the Situation in France." In Migration, Squatting and Radical Autonomy, edited by Pierpaolo Mudu and Sutapa Chattopadhyay, 67-77. Abingdon: Routledge.

Butler, Judith. 2015. Notes toward a Performative Theory of Assembly. Cambridge, MA: Harvard University Press. 
Coutant, Isabelle. 2017. "Le lycée, les migrants, le quartier, les habitants." Plein Droit, no. 115: 15-18.

- 2018. Les migrants en bas chez soi. Paris: Éditions du Seuil.

Couvelaire, Louise. 2016. "Le centre pour migrants ouvre ses portes à Paris." Le Monde Online, 10 November. http://www.lemonde.fr/immigration-etdiversite/article/2016/11/10/le-centre-pour-migrants-ouvre-ses-portes-aparis_5028547_1654200.html.

Degeorges, Marion. 2016. "Les migrants et leurs soutiens défilent à Paris face à la menace d'une évacuation de leur camp." Le Monde Online, 2 November. http:// www.lemonde.fr/societe/article/2016/11/o2/une-manifestation-de-migrantsdans-le-nord-de-paris_5024402_3224.html.

Derveaux, Benjamin. 2015. "Dans le jardin du Bois-Dormoy, une solidarité précaire pour les migrants de La Chapelle." Le Monde Online, 11 June. http://www.lemonde. fr/immigration-et-diversite/article/2015/o6/11/dans-le-jardin-du-bois-dormoyune-solidarite-precaire-pour-les-migrants-de-la-chapelle_4651856_165420o.html.

Fassin, Didier. 2012. Humanitarian Reason: A Moral History of the Present. Berkeley: University of California Press.

France Info. 2015. “VIDEO. Réfugiés: bienvenue ?” Envoyé Spécial, 10 September. https://www.francetvinfo.fr/replay-magazine/france-2/envoye-special/videorefugies-bienvenue_1078951.html.

Jaoul, Nicolas. 2015a. "A propos de la médiatisation de la Maison des Réfugiés." Médiapart, 22 October. https://blogs.mediapart.fr/la-chapelle-en-lutte/blog/221015/ propos-de-la-mediatisation-de-la-maison-des-refugies-par-nicolas-jaoul.

—. 2015b. "Stigmatiser la solidarité avec les réfugié-es: le discours officiel de la manipulation politique et ses implications." Médiapart, 14 July. https://blogs. mediapart.fr/la-chapelle-en-lutte/blog/140715/stigmatiser-la-solidarite-avecles-refugie-es-le-discours-officiel-de-la-manipulation-poli.

- . 2019. "Bariz (Paris), le temps des campements: filmer la lutte des migrants. Entretien de Nicolas Jaoul par Corinne Fortier." Revue Science and Video, no. 9. http://scienceandvideo.mmsh.univ-aix.fr/numeros/9/Pages/og-og.aspx.

Jaoul, Nicolas, and Chowra Makaremi. 2015. "Les réfugiés de La Chapelle victimes d'une répression disproportionnée." Le Monde Online, 12 June. http://www. lemonde.fr/idees/article/2015/o6/12/les-refugies-de-la-chapelle-victimes-d-unerepression-disproportionnee_4653244_3232.html.

La Chapelle en lutte. 2015. "Appel de soutien aux migrants de la Chapelle." Médiapart, 19 June. https://blogs.mediapart.fr/la-chapelle-en-lutte/blog/190615/ appel-de-soutien-aux-migrants-de-la-chapelle.

Lamothe, Jérémie. 2015. "A Paris, des migrants invitent leurs nouveaux voisins." Libération Online, 2 August. http://www.liberation.fr/societe/2015/08/02/a-parisdes-migrants-invitent-leurs-nouveaux-voisins_1357851. 
Lamothe, Jérémie, and Sofia Fischer. 2015. "Migrants: 'La Chapelle', collectif très solo." Libération Online, 7 August. http://www.liberation.fr/societe/2015/08/o7/ migrants-la-chapelle-collectif-tres-solo_1360367.

Lamothe, Jérémie, and Marine Le Gohébel. 2015. "Au lycée Jean-Quarré, les migrants s'installent." Libération Online, 3 August. http://www.liberation.fr/ societe/2015/o8/o3/au-lycee-jean-quarre-les-migrants-s-installent_1358311.

Le Figaro Online. 2015a. "À Paris, des migrants occupent une caserne pendant plusieurs heures." Le Figaro Online, 11 June. http://www.lefigaro.fr/actualitefrance/2015/o6/11/01016-20150611ARTFIG00424-a-paris-une-centaine-demigrants-investissent-une-caserne-desaffectee.php.

—.2015b. "Paris: les migrants réfugiés dans un lycée désaffecté ne seront pas expulsés." Le Figaro Online, 3 August. http://www.lefigaro.fr/flash-actu/2015/08/03/9700120150803FILWWWo0244-paris-les-migrants-refugies-dans-un-lycee-desaffectene-seront-pas-expulses.php.

Le Monde Online. 2015. "Plus de 1300 migrants évacués du lycée désaffecté JeanQuarré à Paris." Le Monde Online, 23 October. http://www.lemonde.fr/societe/ article/2015/10/23/plusieurs-centaines-de-migrants-evacues-du-campementjean-quarre-a-paris_4795331_3224.html.

Merhaba. 2015a. "Merhaba no. 1." https://merhaba.noblogs.org/files/2016/03/ merhaba1-en.pdf.

Merhaba. 2015b. "Merhaba no. 2." https://merhaba.noblogs.org/files/2016/o3/ merhaba2-en.pdf.

Merhaba. 2015c. "Merhaba no. 3." https://merhaba.noblogs.org/files/2016/o3/ merhaba3-1-en.pdf.

Merhaba. 2016a. "Merhaba no. 4." https://merhaba.noblogs.org/files/2016/o3/ merhaba4en.pdf.

Merhaba. 2016b. "Merhaba no. 5." https://merhaba.noblogs.org/files/2016/05/ merhaba5en.pdf.

Monforte, Pierre. 2014. Europeanizing Contention: The Protest against "Fortress Europe" in France and Germany. Oxford: Berghahn.

Mouillard, Sylvain, and Frantz Durupt. 2015. "La situation 'pas tenable' des migrants du nord de Paris.” Libération Online, 9 June. https://www.liberation.fr/societe/2015/o6/og/la-situation-pas-tenable-des-migrants-du-nord-de-paris_1326378.

MSF. 2016. "Migrants dans la rue à Paris: le harcèlement et les violences policières doivent cesser.” Médecins sans frontières, 7 January. https://www.msf.fr/ communiques-presse/migrants-dans-la-rue-a-paris-le-harcelement-et-lesviolences-policieres-doivent-cesser.

NPA. 2015. “MigrantEs de La Chapelle (Paris 18e): après la rafle 'humanitaire', la lutte continue!" https://npa2009.org/actualite/migrantes-de-la-chapelle-paris-18eapres-la-rafle-humanitaire-la-lutte-continue. 
OFPRA. 2016. "Rapport d'activité OFPRA 2015." Paris. https://ofpra.gouv.fr/sites/ default/files/atoms/files/rapport_dactivite_ofpra_2015_hd.pdf.

Péchu, Cécile. 1999. "Black African Immigrants in France and Claims for Housing." Journal of Ethnic \& Migration Studies 25 (4): 727-744.

Pouliquen, Fabrice. 2016. "Paris: la vie s'organise au lycée Jean-Jaurès occupé depuis cette nuit par des migrants." 20 Minutes Paris. Paris. http://www.2ominutes.fr/ paris/1832383-20160422-paris-vie-organise-lycee-jean-jaures-occupe-depuisnuit-migrants.

Préfecture de Police Île de France. 2015. "Évacuation des occupants du campement implanté boulevard de la Chapelle." http://www.prefectures-regions.gouv. fr/ile-de-france/Region-et-institutions/L-action-de-l-Etat/Cohesion-socialevie-associative-sport-et-jeunesse/Evacuation-des-occupants-du-campementimplante-boulevard-de-la-Chapelle.

—. 2016. "Fiche presse Accueil, hébergement et suivi administratif des migrants à Paris et en Île-de-France - 04 mai 2016." http://www.prefectures-regions.gouv. fr/ile-de-france/content/download/21741/150732/file/Fiche.

Projet Babels. 2017. De Lesbos à Calais: comment l'Europe fabrique des camps. Neuvyen-Champagne: Le passager clandestin.

Sabot, Antonin. 2015. “'On les trie sur le trottoir': les migrants de La Chapelle évacués." Le Monde Online, 2 June. http://www.lemonde.fr/immigration-etdiversite/article/2015/06/02/le-campement-de-migrants-de-la-chapelle-evacuepar-la-police_4645361_165420o.html.

Simon, Cyril. 2015. "Au lycée Jean-Quarré, le dialogue reprend entre les réfugiés et la mairie." Le Monde Online, 22 September. http://www.lemonde.fr/societe/ article/2015/og/22/au-lycee-jean-quarre-le-dialogue-reprend-entre-les-refugieset-la-mairie_4767364_3224.html.

Ticktin, Miriam. 2011. Casualties of Care: Immigration and Politics of Humanitarianism in France. Berkeley: University of California Press. 
